\title{
Reconsidering Comparative Methodology in Administrative Law
}

\author{
Roberto Scarciglia \\ Department of Political and Social Sciences, University of Trieste, Trieste, Italy \\ Email: roberto.scarciglia@dis pes.units.it
}

How to cite this paper: Scarciglia, R. (2019). Reconsidering Comparative Methodology in Administrative Law. Beijing Law Review, 10, 1051-1065.

https://doi.org/10.4236/blr.2019.104056

Received: August 26, 2019

Accepted: September 22, 2019

Published: September 25, 2019

Copyright $\odot 2019$ by author(s) and Scientific Research Publishing Inc. This work is licensed under the Creative Commons Attribution International License (CC BY 4.0).

http://creativecommons.org/licenses/by/4.0/

\begin{abstract}
What are the forms of comparison in administrative law? Which impact do methodological approaches, both theoretical and practical, on comparative research in administrative law? This article proposes some reflexions on these questions, also considering the historical origins of comparison in administrative law. Unlike private and constitutional law, administrative law is a young, comparative legal discipline, and this is one of the main reasons because the interest in comparison in administrative law has been neglected until the beginning of the 1990s of last century. Global issues-such as migrations, international terrorism, wars, environmental changes or recent economic crises-require a rethinking of comparative analysis from a pluri-methodological (and multidisciplinary) point of view. In the second part of the article, I will try to analyze the use of comparative law methodology for administrative law research.
\end{abstract}

\section{Keywords}

Comparative Methods, Administrative Law, Methodological Choices, Globalization, Methodological Pluralism

\section{Introduction}

Administrative law is a not very old discipline: it is a late fruit of history, produced by the accumulation of heterogeneous and sedimented over time, factors, and its origin is in the eighteenth-century. However, a study of historical forms of administration has in any case been a useful aid to understand the origins of modern administrative law, especially in non-European countries. This phenomenon is suitable with reference to feudal-such as the Persian Empire, the great Muslim states, the Manchu Empires in China, and the Shogun in Japan-and post-feudal monarchies to the cities and rural communities of me- 
dieval Europe, from the Republic of Venice to the first constitutional forms of administration (Ghose, 1919; Heidborn, 1908-1909).

Before the formation of a science of administrative law in Europe, civil and common lawyers frequently used the comparison to analyze foreign systems between the early sixteenth and the eighteenth century. It was not a mature form of comparison, in the absence of a methodological approach, which began to be used only by the first Congress of Comparative Law held in Paris in 1900 and organized by Edouard Lambert and Raymond Saleilles. Professor Lambert's lecture on the general theory and methodology of comparative law represented the starting point of a new and autonomous science and clarified the essential functions of comparative law. According to their "realistic" theory, Saleilles, Lambert and Lévy-Ulmann pointed out that comparison is a mechanism to improve the law.

Comparative activities tended to seek concordance between the laws of different regions or countries and constituted the so-called "communis opinio" or "praxis totius orbis" (totius Europae), which was of great importance in solving the controversial court cases. This activity was sometimes determined by the fragmentation of territories in Europe, as in the case of German principalities or Italian states, which were too small to develop an exportable model or a doctrinal systematization (Rivero, 1969). With the transition from the ius commune to "national" legal orders between the sixteenth and eighteenth centuries, a substantial identity of models, methods and attitudes (Cassese, 1992) - and their circulation and convergence-was typical of these systems, called "open legal orders" (Gorla, 1989).

During the Age of Enlightenment, there was an increased interest for comparative analysis of foreign legislation, with the aim of inspiring reforms or, at least, improving the national law, and this research of symmetries continued throughout the latter half of the nineteenth century. The foundation of national legal sciences involved a process of closing the mechanisms of circulation of European law, and especially of principles of administrative law. However, in spite of this process, the tension of scholars towards comparison did not diminish.

When is the term "comparative administrative law" used for the first time? The answer to this question can be useful in understanding the origin, scope and legal facts that preceded the formal existence and its definition in the textbooks of administrative law.

\section{Origins of Comparison in Administrative Law}

The circulation of models and the use of comparative methodology favored the publication of the first books of comparative administrative law-such as that of Batbie (Batbie, 1862-1868), started in 1862, Goodnow (Goodnow, 1902) in 1893, and Brunialti (Brunialti, 1912-14) at the beginning of the new Century. These books represented a first attempt to outline the foundations of a legal science in progress and to isolate the main convergences between laws belonging to different legal families, but to communicating systems. Goodnow's work contained 
the idea that the starting point for comparison in administrative law is to trace the boundaries of this legal science, which, from a material point of view, did not coincide if we analyze civil and common law systems.

He expressed the intention to illustrate, on the one hand, "the methods of administrative organization adopted in [...] United States, England, France, Germany». And, on the other, he described the sphere of administrative action, identifying powers and functions of public bodies, the rights granted to citizens and the sanctions for their violation.

Goodnow and Batbie's works contain much information, according to Wigmore's approach in A Kaleidoscope of Justice (Wigmore, 141), but today we can consider these books as methodologically disappointed, particularly for a straining of the alleged homogeneity of national administrative systems, without analyzing similarities and differences.

From a comparative point of view, we find more interesting the works by Indian scholars, Dwarka Nath Mitter (Mitter, 1916), in 1916 and Nagendra Nath Ghose (Ghose, 1919), in 1919, in which they use a comparative approach to analysing the legal systems and administrative authorities in Great Britain and India during the colonial period.

At the expense of the two world wars, the suspension of the open process that had also affected the comparison in administrative law and the reception mechanisms had come true. Only at the end of the second world conflict, there were a systematic study, and university courses, of comparative administrative law. A negative attitude toward laws in other countries had strengthened the tendency for using comparative research about different legal systems to reinforce the conviction of the superiority of one over another.

The reasons for this behavior reside mainly in the conviction that administrative law presents a typically national mark, as a consequence of some factors. We can point out the achievement of a relative stability of European structure, the apogee of the British Empire, the realization of the first models of administration, the development of national laws as the primary sources of law, with the consequent prevalence of a separation logic rather than convergence.

After the Second World War, there was a remarkable interest in comparative law, particularly in private and public (constitutional and administrative) law. The adoption of new Constitutions in Europe (Germany, Italy) and the development of the external relationship, like, for example, the United States and Russia, contributed to revitalize this comparative science. An intense scientific production, conferences and congresses dedicated to the comparative methodology, and the creation of research institutes and new legal journals, were evidence of this trend. In the fifties, and at the beginning of the sixties, some indicators pointed to comparative law having a significant development in the countries of Western legal tradition. As far as other parts of the world-such as East Asia-the term "administrative law" was unknown and comparative studies benefited i.e. from the use of historical materials to understand the links between traditional East Asian law with modern administrative law (Ohnesorge, 2010). 


\section{What Is Comparative Administrative Law?}

Administrative law and its history related to the emergence and development of public powers within the European Nation-States. This is a particularly complex phenomenon analyzed through some ideal types such as the Rechsstaat, the Etat de Droit and the Rule of Law (Sordi, 2010; Bignami, 2012). According to Rivero, in the world of legal comparison, administrative law is often seen as the poor relative to research, unlike private law and constitutional law (Rivero, 1955-1956). There were different reasons. On the one hand, there was the difficulty of traveling and developing relations with administrations of other countries. On the other, we can find the contrast between the purpose of uniformity of law by comparatists, as well as the diversity of administrative law in European countries.

In the first books containing the expression 'comparative administrative law'-as well as many subsequent ones-there was no room dedicated to the methodology, with the consequence that the scientific community didn't promote this discipline. Then, any science cannot define it without a method. So also administrative law cannot separate itself from knowledge and application of one or more comparative methods, which are necessary elements for the determination of an autonomous discipline.

The intimate connection between methodology, purpose, and content of inquiry would tend to exclude that one could determine one or more methods for research, regardless of object and purpose. Methodology emphasizes certain peculiarities, especially on the side of the comparison results, which can justify the autonomy of comparative disciplines such as comparative private law, comparative constitutional law, comparative criminal law, and finally comparative administrative law.

This path begins, like all other comparative disciplines, with the 1900 Paris International Congress on Comparative Law. Over time, comparative methodology contributed to a consolidation of comparative constitutional law, based on the principle that a proper comparison-as an intellectual transaction between legal rules, institutions, and their components-must be carried out systematically and according to the style of legal methodology. Only in this way we can consider it as a scientific discipline (Hirschl, 2008). The same has happened with administrative law. Many years have passed since the publication of the first textbooks-by Basu (Basu, 1969; Jacobini, 1991), Goodnow (Goodnow, 1902). and Ghose (Ghose, 1908-1909) - and many books and articles on comparative administrative law topics have been published. At this point, we can conclude that comparative administrative law as a field of study-supported by the use of comparative methodology - on "the general principles that govern the powers and obligation of public authorities" (Bell, 2006). It can be further divided into the study of fundamental rights (e.g. rule of law and fundamental rights), the standards of good administration, the powers of administration, the administrative organizations, the administrative procedures, the procedures and institu- 
tions of judicial review, the liability of the administration (Bell, 2006).

\section{Technical Approaches in Comparative Administrative Law}

The central part of this short essay is devoted to the use of comparative methodology in administrative law. In a recent book, I have tried to demonstrate the need for knowledge of the methodology for a comparatist, where he/she wants to venture into the "deep" comparison, avoiding the surface (Scarciglia, 2018). This view finds evidence in many papers-containing the expression 'comparative law' in the title-but which do not go beyond the description of institutions and legal systems. Although there have been sophisticated proposals for the use of the methodology in research, such as the comparison between the various methods used for analysis in administrative law (Ruffert, 2007), you may well share the idea that this approach has been less present than in private or in constitutional law (Boughey, 2013).

Methodological choices for research in comparative law may be technical or theoretical. These two approaches, of course, also applies to administrative law. I will consider only some of the different technical choices, more useful in comparative administrative law. From this point of view, the first division is between micro and macro-level (Wigmore, 1941).

\subsection{Macro und Micro-Comparison}

The terms "macro-comparison" and "micro-comparison" are closely related to different modes of conducting a comparative inquiry. This form of classification is not just about comparative law, but it is also useful in economics, medicine, sociolinguistics, and other sciences. The comparative methodology is not always present in administrative law books, and references to foreign orders are often descriptive. According to Bell, we can say that "the mere collation or confrontation of information about different legal system" is not a comparison (Bell, 2006). However, this character is most visible when it exponentially increases the number of legal systems that we choose for comparison. Otherwise there is "one greater range topics for micro-comparison and, again, the primary purpose or main aims and objectives of comparison will determine the selection of topics" (de Cruz, 1999).

Micro-comparison can be used in a large part of administrative law: from the administrative organization to the action of the public powers, from the legislative statements to the administrative procedure, from the administrative remedies to the administrative justice and tribunals. This list is only indicative. Legal scholars use a micro-comparison approach for many objects. On the contrary, macro-comparison focuses on legal systems or legal and cultural traditions ( $\mathrm{Hu}-$ sa, 2015; Cuniberti, 2011). Although the border between the two technical alternatives is very flexible, one element, which marks the difference, is surely the high level of abstraction that characterizes comparative analysis. Moreover, 
comparative research can present both perspectives, even if the theoretical choices will go to affect the prevalence of one or the other, without excluding, however, a relationship between micro and macro-comparison.

From the point of view of macro-comparative law, one of the most studied topics is the classification of legal systems, or even the models of administrative law. In that regard, we can say that history, culture, and traditions have allowed forms of aggregation of the different systems. According to Husa, we can distinguish some basic blocks of macro-comparison: common law, continental or civil law, mixed legal systems, religious-traditional law and socialist legal family (Husa, 2015).

The most recent classification proposals take into account some of these assumptions, such as, in particular, the existence of mixed legal systems, the almost disappearance of the socialist model, or the emergence of ever-increasing forms of pluralism. However, these classifications, above all, have in common the overcoming of the idea that legal systems and legal entities are "static and isolated entities" (Reimann, 2002). On the contrary, legal systems enter, too often, in contact with external elements, which produce forms of contamination. This phenomenon happened to all European legal systems and to other parts of the world, where, i.e., common law runs into the principles of religious law or indigenous customary law, such as in India and Pakistan.

However, we must consider all forms of classification, taxonomies, groupings, with particular attention, because in some cases it depends on the cultural formation-sometimes ethnocentric-of the scholars who propose this model and the rapid transformation, generated by global phenomena (Reimann, 2002; Husa, 2004).

If we want to introduce a first classification with reference only to the traditions of administrative law of the States of the European Union, we could classify them in four different models: French, German, Mixed and British (Fromont, 2006). In the first group (French), in addition to France, there are Netherlands, Belgium, Italy and Greece. The Germanic group includes Germany, Austria, Switzerland, and Poland. A third group-which we could define as a mixed one-involves countries that have undergone the influence of French law, such as Spain and Portugal, Sweden and Finland. Finally, the British group is part of the Swedish and Finnish law, in addition to the United Kingdom and Ireland.

About these classifications-and the criticisms sometimes made by some scholars-we can observe that, particularly in administrative law, the homogeneity of specific areas and the sharing of models can make comparisons particularly useful. There are, e.g., comparative inquiries focusing on the common law world (Cane, 2016) and in comparison with French administrative law, also analyzing the influence of this model outside France (Neville Brown \& Bell, 1993) or England (Lobingier, 1942).

\subsection{Longitudinal and Transverse Comparison}

The second of the methodological choices of a technical nature regards the time 
dimension in comparison. One can indifferently talk about "longitudinal" and "transverse," or also about "synchronous" and "diachronic" comparison. These terms indicate, on the one hand, that the comparison between two or more legal systems occurs at present; on the other, that it develops itself between present and past, by analyzing materials that have a present normative validity and other materials that lost this force. Many administrative law books containing a comparative approach are characterized by the use of a synchronic analysis, although the rapid transformation of institutions and legislation sometimes implies to consider its historical evolution.

On the other hand, there are essential works characterized by a diachronic comparison, such as, for example, the book by Cane, Controlling Administrative Power (Cane, 2016). According to Rhodes, a good comparison needs to explore both the evolution of Institutions and their operation', specific events, eras, people and institutions, searching for regularities across time and countries in diachronic comparison (Rhodes, 2006).

Moreover, quoting Maitland's words-"History involves comparison"36-we can certainly say that if we compare, and especially in the field of public law, that implies a necessary historical knowledge. A comparatist instinctively looks with the eyes of an historian beyond any form of conceptualization or classification, with freedom and without prejudices, both we study domestic or foreign law. The two temporal perspectives-synchronic and diachronic-are not incompatible, and their simultaneous use in research on administrative law matters is sometimes necessary, particularly when the analysis concerns complex problems or significant transformation of consolidated institutions.

According to Peter Cane:

[i] ndeed, historical accounts of the development of institutions may be, and perhaps typically are, made up of a set of observations at several particular points of time rather in the way that a moving picture is made up of a series of still (Cane, 2016).

\subsection{Horizontal and Vertical Comparison}

'Horizontal' comparison is a comparative analysis of legal systems at the same level. In order to outline new directions in comparative law, we could say that legal comparison is mainly horizontal. Legal scholars are used to compare legal systems or institutions belonging to the same level, both national (i.e., for comparative constitutional law) and international level (i.e. comparing international institutions) (Momirov \& Fourie, 2009).

Many of these scholars are today devoted to the study of global law, highlighting the need to use the comparative method, and this does not necessarily mean that they have to consider only a horizontal form of legal comparison. This way could ignore the existence of legal transplants, as well as a development of principles and rights in a global space. An imposition of global rules at the national level or the adoption in a global sphere of principles and values of a domestic legal system oblige legal scholars to rethink the use of comparative me- 
thodology.

However, we can shift our focus from horizontal to vertical methodology in comparative law. For 'vertical comparison', I mean not only the analysis of successive forms of the same legal system, but also the comparison between systems, or legal institutions, do not belong to the same level. An example of this could be given by an analysis of Chinese public administration and reforms during Mao and post-Mao China.

From a vertical point of view, comparative methodology can be vertical top-down or bottom-up. In the first case, we can use this mode of legal comparison "i.e. typically in the context of the internalization of norms and regulations by national legal orders, whereby national law is required to incorporate international concepts into the national legal system" (Momirov \& Fourie, 2009). In the second case, we can use vertical bottom-up legal comparison, analyzing "the transposition of legal concepts, or the ideas behind them, from national to international level" (Momirov \& Fourie, 2009). For example, in constitutional law, the comparison is horizontal when one might take into account national legal systems (or their legal formants) or even national systems in relationship with supranational legal systems.

In terms of vertical comparison, there is a further approach used in cases in which international standards incorporate national principles (Chodosh, 1999). Some analytical studies on vertical comparative methodology are in the field of administrative law. A starting point for analyzing this issue could be the paper by Felix Frankfurter, published in 1927 in the University of Pennsylvania Law Review, and entitled 'The Task of Administrative Law' (Frankfurter, 1927).

When analysing the relationship between judicial review and administrative law, he notes that therefore, a subject like "judicial review", in any scientific development of administrative law, must be studied not only horizontally, but vertically, i.e., "judicial review" of Federal Commission orders, "judicial review" of postal fraud orders, "judicial review" of deportation warrants. For judicial review in postal cases, for instance, is colored by the whole structure of which it forms apart, just as in land office cases, or in immigration causes or in utility valuations or in insurance license revocations, it derives significance from the nature of the subject matter under review as well as from the agency which is reviewed (Frankfurter, 1927).

However, in the comparative process one might have to use different methodologies according to the function that one intends to carry through the comparison. The methods of comparative law have developed over time and comparatists are always in search of something new (Chodosh, 1999). This is also justified by the fact that there are different categories of people who make use of comparative law: scholars or academic comparatists, legislative or reform comparatists and law-applying comparatists (Palmer, 2004).

They can use different methodologies because there are different purposes that the comparison pursues. Although the horizontal comparison is certainly more widespread, we will only consider forms of vertical comparison and, in 
particular, a top-down and a bottom-up approach. The former regards the mobility of legal concepts from national to international levels and vice-versa.

The reasons, we rethink the use of the comparative methodology, and, particularly, developing a cross-echelon comparison, are different.

We will shortly describe two. First, before the 90s, we use legal comparison and transpositions of legal concepts, from one legal system into another, by "horizontal" methodology. However, in the following years, transnational interactions, global commerce, a rapid development of web communication, such as the global economic crisis, have led to greater complexity in the analysis of legal phenomena.

Consequently, this complexity had impact on the way to make legal comparison and circulation and integration of legal rules and models. In this regard, Gutteridge noted that "any relationship or kinship between comparative law and the law of nations must, therefore, be of a shadowy nature, and the only possible link between the two disciplines is to be found in the extent to which the comparative study of private law can be regarded as an instrument to be employed in promoting the growth and development of the law of nations" (Husa, 2015).

We could consider that "the integration rules can present a high degree of complexity, mainly from the institution of new procedures that allow producing these rules. In any case, it does not propose changes on the closing of the system" (Pfersmann, 2001). This setting of the problem does not however, help to analyze all those cases in which the mobility and the transplantation of legal concepts occur in different forms, and sometimes in a tacit form.

\section{Theoretical Approaches in Comparative Administrative Law}

Beside the technical methodological choices, a comparatist has at disposal some theoretical alternative: a) functional comparison; b) structural comparison; c) systemic comparison and d) critical comparison (Husa, 2015). Let us see if these approaches can combine with technical choices and, in particular, whether they apply to administrative law. As Husa points out, the use of different methods can be challenged by a specialist knowledge, for example, of a professor of administrative law, but it is also true that a choice does not exclude other approaches (Husa, 2015). Moreover, although it is true that each discipline prefers different comparative approaches, their choice depends on the nature and aims of the scientific project (Adams \& Bomhoff, 2012).

\subsection{Functional Comparison}

Comparative law has, between its aims, the solution of problems of comparability with an approach that tends to enhance the look depth of law. In particular, the functional comparison pursues the equivalence of phenomena, which, while having the same function, they are structurally different (Michaels, 2012; Zweigert \& Kötz, 1998; Graziadei, 2003; Legrand, 2006).

As Vicki Jackson observes, "[t]he methodological categories have a remarka- 
ble overlap, and a single work can include examples of different methodologies, such as, for example, classification work and functional analysis" (Jackson, 2012). Classical functionalism characterizes itself by searching for similarities and convergences, unlike a recent neo-functionalist orientation looking for similarities and differences and, in a post-modern version; it focuses rather on dissimilarity and differences.

As it happens with constitutional law, the use of the functional method for the macro-comparison is not fruitful where we decide to compare families or legal cultures from the administrative law point of view. The results that the comparatist achieves will highlight the goodness of the method, or methods, chosen and the possible prescriptiveness of the results.

In any case, the functional method does not rule out the simultaneous presence with other methods. In any case, the functional method does not rule out the simultaneous presence with other methods. A functional comparatist is simultaneous "out" and "in" the law, and functionalism represents a reasonably flexible way to allow brilliant results in comparison, though it is not always easy to define what function does a legal institute or a rule in two different legal systems.

\subsection{Structural Comparison}

Structuralism' is a methodology according to which each object of inquiry constitutes a "structure", an organic set whose elements do not have autonomous functional value but they assume it in the oppositional and distinctive relationships of each element with regard to all others of the whole. We can say it is a specialised application of functional comparison (Husa, 2015). According to Husa, when a researcher find structurally similar elements, he must realize what socio-legal functions these factors have in the legal systems object of inquiry, and 'how they were born and acquired their present form (Husa, 2015).

This methodological approach allows both to define consonances and dissonances in different fields of law, within the legal systems that we compare as well as, at the level of micro-comparison, the specific meaning of a term within a legal system. From comparative law point of view, Rodolfo Sacco, an Italian comparatist, gave the most significant contribution, between functionalism and structuralism, formulating the theory of "legal formants" (Sacco, 1991).

Since the late 1990s, also legal scholars in public law followed this theory. The reasons were many: different normative spheres began to interweave, such as a new interest for the historical method and methodological pluralism, discovering non-Western legal and cultural traditions. A pluralist approach has favored the overcoming of the contrasting tendency between different ways of comparison-and their exclusive use-allowing, for example, going beyond the limitation of choice between functionalism and structuralism.

\subsection{Systemic and Critical Comparison}

The systemic approach of comparison has as a goal the analysis of a legal institu- 
tion or a structural element that belongs to a specific legal order analyzed separately from the correspondent national context, and compared to other solutions coming from different legal systems (Husa, 2015). The researcher, studying an institution or a rule in different legal systems, highlights a theoretical context (comparative framework). In the field of public law, there are many studies on the systemic comparison, such as the administrative procedure or adjudication.

The critical approach is different from the others previously examined. According to Husa, there two different types of criticalness: 1) attitude to earlier comparative law is critical and it considered to concentrate too much on Western [...] law similarities and practical goals; and 2) in the study approach the aim is to include dimensions that are not descriptive to as great an extent as the case has been in traditional comparative law (Husa, 2015).

The use of this approach for comparison administrative laws, if theoretically possible, could be confusing because the nation states have a typical ethnocentric connotation, and the prototypes of administrative law-both English, French and German-have been circulated throughout the world. On this point, we can point out, i.e., German (and the US) model forged some parts of administrative law in East Asia.

\section{Concluding Remarks: Towards a Pluralist Methodology for Administrative Law?}

In the preceding paragraphs, we have reminded of the problem of the functionality concerning the methodological tools, dealing with the complexity that characterizes various legal phenomena involving administrative issues and law. The debate on methodology suffers from these issues, and it is not surprising that we can use in our comparative inquiries, a "sliding scale of methods," as Vernon Palmer highlights (Palmer, 2004). Undoubtedly, the functional approach carries out a sort of methodological paradigm, i.e., both in private and constitutional or administrative law.

However, that does not rule out that the methodological choices which precede a comparative analysis in administrative law-as with other legal fields-may belong to all the technical or theoretical approaches. The researcher, usually, begins to think about it after the gathering of data, when he has an initial design. When starting the initial phase of a comparative inquiry, one often wonders if the methods by which he analyzed legal systems in the past or their components are adequate also in a transnational context (Hey \& Mak, 2009). We have to adapt the choice to the specific purposes of the inquiry, to the higher or less complexity and the expected results. Necessarily, one should make a comparison between different methodological options. The best methodological choice is therefore not definable without first analyzing the variables related to the methodological choices.

In truth, the search of the most suitable methodology to analyze the dynamic mechanisms of transformation of institutions and administrative law, in and out of Europe over the past two decades, was a recurring topic (Ruffert, 2007; 
Seerden, 2012; Ginsburg \& Chen, 2009). If we look at this issue from a non-ethnocentric perspective, we will be able to begin an inquiry by taking away our legal mentality. These transformations changed not only the way of studying the sources of administrative law but also, above all, to compare them by interpreting the differentiation factors present in the legal systems and different administrative traditions, such as French, German or English. The interpreter meets, alongside the national sources of administrative law many others as well supranational, non-state-such as religious, personal, customary laws-and other forms of soft law (Twining, 2007).

According to Michaels, "the plurality of legal systems, the coexistence of laws of states with other rules 'beyond states', the absence of a position hierarchically superior that transcends the differences, all of these arguments of legal pluralism reappear on the global sphere" (Michaels, 2009).

In addition, it is no accident that administrative law has played a key role in solving problems arising from global phenomena like emigration, environment, detention in prison, religious symbols in places of worship, administrative violations and cultural factors.

From this point of view, social and cultural factors can be useful for understanding (and discovering) the best practices and solutions-or even just simplifications and procedures - to highlight differences or invariants, respectively by the use of critical and/or structural comparative approaches (Bell, 2011).

Moreover, the emergence of global administrative law tends to complicate this picture: it needs to use also horizontal and vertical comparisons (Cassese, 2016). The speed with which these phenomena move, and require responses, to administrative law scholars. It also advances the growing need to know the various methodological approaches to comparison. One might start this reflection with the procedural phase of knowledge, starting from a full reading of technically the materials that can involve "his epistemological prejudices, his attitude towards the absurd consequences of the theories which he accepts", as well as the methods that he/she uses in his analysis (Adams \& Griffith, 2012).

That is a broader comparison, but necessary to address the challenges of comparative administrative law in the new century. Furthermore, the idea of using different approaches in legal comparison has gone way also in international law, where legal scholars are developing a debate on the use of the comparative methods, a first step to create a new field of comparative law (Roberts, Stephan, Verdier, \& Versteeg, 2015).

So how can we reconsider the comparative methodology in administrative law? Although functionalism has played-and plays-an essential role in comparing, the development and the knowledge of a plurality of methods-that we can define as "methodological pluralism" (Scarciglia, 2014) - it is necessary to address the complex issues and problems that even administrative law is facing in the global or post-global times. That is a new frontier, and an extraordinary opportunity, for (new) comparative scholars, and a renewed attention to this 
rich field of study.

\section{Conflicts of Interest}

The author declares no conflicts of interest regarding the publication of this paper.

\section{References}

Adams, M., \& Bomhoff, J. (2012). Comparative Law Practice and Theory: The 'Missing Middle'. In M. Adams, \& J. Bomhoff (Eds.), Practice and Theory in Comparative Law. Cambridge: Cambridge University Press. https://doi.org/10.1017/CBO9780511863301

Adams, M., \& Griffiths, J. (2012). Against 'Comparative Method': Explaining Similarities and Differences. In M. Adams, \& J. Bomhoff (Eds.), Practice and Theory in Comparative Law (pp. 27). Cambridge: Cambridge University Press.

Basu, D. D. (1969). Comparative Administrative Law. Calcutta: S.C. Sarkar.

Batbie, A. (1862-1868). Traité théorique et pratique de droit public et administratif contenant l'examen de la doctrine et de la jurisprudence; la comparaison de notre législation avec les lois politiques et administratives de l'Angleterre, des Etats-Unis, de la Belgique, de la Hollande, des principaux Etats de l'Allemagne, et de l'Espagne, la comparaison de nos institutions actuelles avec celles de la France avant 1789 et des notions sur le sciences auxiliaires de l'administration, l'économie politique et la statistique, I-VIII. Paris: L. Larose Éditeur.

Bell, J. S. (2006). Comparative Administrative Law.

Bell, J. S. (2011). Legal Research and Comparative Law. In M. Van Hoecke, (Ed.), Methodologies of Legal Research (pp. 169). Oxford: Hart Publishing.

Bignami, F. (2012). Comparative Administrative Law. In M. Bussani, \& U. Mattei (Eds.), The Cambridge Companion to Comparative Law (pp. 145). Cambridge: Cambridge University Press.

Boughey, J. (2013). Administrative Law: The Next Frontier for Comparative Law. International and Comparative Law Quarterly, 62, 55-95.

https://doi.org/10.1017/S0020589312000553

Brunialti, B. (1912-1914). Il diritto amministrativo italiano e comparato nella Scienza e nelle Istituzioni, I-II. Torino: Utet.

Cane, P. (2016). Controlling Administrative Power: An Historical Comparison. Cambridge, Cambridge University Press. https://doi.org/10.1017/CBO9781316550878

Cassese, S. (1992). Il problema della convergenza dei diritti amministrativi: verso un modello amministrativo europeo? Rivista trimestrale di diritto e procedura civile, 463.

Cassese. S. (2016). Research Handbook on Global Administrative Law. Cheltenham and Northampton, MA: Edward Elgar. https://doi.org/10.4337/9781783478460

Chodosh, H. E. (1999). Comparing Comparisons: In Search of Methodology. Iowa Law Review, 84, 1025-1038.

Cuniberti, G. (2011). Grands Systèmes de droit contemporains (2nd ed.). Paris: L.G.D.J.

De Cruz, P. (1999). Comparative Law in a changing world (2nd ed., pp. 228). London, Sidney: Cavendish Publishing Limited.

Frankfurter, F. (1927). The Task of Administrative Law. University of Pennsylvania Law Review and American Law Register, 75, 614-621. https://doi.org/10.2307/3307587

Fromont, M. (2006). Droit aministratif des États européens (pp. 13-70). Paris: Puf. 
Ghose, N. N. (1919). Comparative Administrative Law (pp. 27-74). Calcutta: Butterworth.

Ginsburg, T., \& Chen, A. H. Y. (2009). Administrative Law and Governance in Asia. Comparative Perspectives. London and New York: Routledge. https://doi.org/10.4324/9780203888681

Goodnow, F. J. (1902). Comparative Administrative Law: An Analysis of the Administrative Systems National and Local, of the United States, England, France and Germany. NewYork and London: G P Putnam's Sons.

Gorla, G. (1989). Diritto comparato e straniero. In Enciclopedia Giuridica, XI (pp. 12). Roma: Treccani.

Graziadei, M. (2003). The Functionalist Heritage. In P. Legrand, \& R. Munday (Eds.), Comparative Legal Studies: Traditions and Transitions (pp. 114-116). Cambridge, Cambridge University Press.

Heidborn, A. (1908-1909). Manuel de Droit Public et Administratif de l'Empire Ottoman, I II. Vienne-Leipzig: C W Stern.

Hey, E., \& Mak, E. (2009). Introduction: The Possibilities of Comparative Law Methods for Research on the Rule of Law in a Global Context. 2 Erasmus Law Review, 3, 287.

Hirschl, R. (2008). The Rise of Comparative Constitutional Law: Thoughts on Substance and Method. 2 Indian Journal of Constitutional Law, 13.

Husa, J. (2004). Classification of Legal Families Today: Is It Time for a Memorial Hymn? Revue internationale de droit comparé, 56, 11-38. https://doi.org/10.3406/ridc.2004.19249

Husa, J. (2015). A New Introduction to Comparative Law (pp. 102). Oxford and Portland, OR: Hart Publishing.

Jackson, V. C. (2012). Comparative Constitutional Law: Methodologies. In M. Rosenfeld, \& A. Sajó (Eds.), The Oxford Handbook of Comparative Constitutional Law (pp. 54-74). Oxford and New York, Oxford University Press. https://doi.org/10.1093/oxfordhb/9780199578610.013.0004

Jacobini, H. B. (1991). An Introduction to Comparative Administrative Law. New York: Oceana Publications.

Legrand, P. (2006). Comparative Legal Studies and the Matter of Authenticity. Journal of Comparative Law, 365.

Lobingier, C. S. (1942). Administrative Law and Droit administrative: A Comparative Study with an Instructive Model. University of Pennsylvania Law Review and American Law Register, 91, 36-58. https://doi.org/10.2307/3309336

Michaels, R. (2009). Global Legal Pluralism. Annual Review of Law \& Social Science, 5, 243-262. https://doi.org/10.1146/annurev.lawsocsci.4.110707.172311

Michaels, R. (2012). The Functional Method of Comparative Law. Comparative Constitutional Law: Methodologies. In M. Rosenfeld, \& A. Sajó (Eds.), The Oxford Handbook of Comparative Constitutional Law (pp. 54-74) Oxford and New York: Oxford University Press.

Mitter, D. N. (1916). Comparative Administrative Law: With Special Reference to the Organisation and Legal Position of the Administrative Authorities in British India. A Thesis for Tagore Lectures for 1917, Containing the Introductory Lecture and the Synopsis of the Succeeding Lectures. Calcutta: Butterworth.

Momirov, A., \& Fourie, N. (2009). Vertical Comparative Law Methods: Tools for Conceptualizing the International Rule of Law. Erasmus Law Review, 3, 291-309.

Neville Brown, L., \& Bell, J. (1993). French Administrative Law. Oxford: Clarendon Press.

Ohnesorge, J. (2010). Administrative Law in Easth Asia: a comparative historical analysis. 
In S. Rose-Ackerman, \& P. L. Lindseth (Eds.), (2010). Comparative Administrative Law (pp. 78-91). Cheltenham, UK and Northampton, MA Usa. Cheltenham, UK and Northampton, MA: Edward Elgar.

Palmer, V. (2004). From Lerotholy to Lando: Some Examples of Comparative Law Methodology. Global Jurist Frontiers, 4, 1-29. https://doi.org/10.2202/1535-1653.1126

Pfersmann, O. (2001). Le droit comparé comme interprétation et comme théorie du droit. Revue Internationale de droit comparé, 53, 275-288.

https://doi.org/10.3406/ridc.2001.17976

Reimann, M. (2002). The Progress and Failure of Comparative Law in the Second Half of the Twentieth Century. American Journal of Comparative Law, 50, 671-700.

https://doi.org/10.1093/ajcl/50.4.671

Rhodes, R. A. W. (2006). Old Institutionalism. In R. A. W. Rhodes, S. A. Binder, \& B. A. Rockman (Eds.), The Oxford Handbook of Political Institutions (pp. 94). Oxford: Oxford University Press.

Rivero, J. (1955-1956). Cours de droit administratif comparé (pp. 11). Paris: Le Cours de Droit.

Rivero, J. (1969). Droit administratif français et droit administratif étrangers. Livre du centenaire de la société de législation comparée. Un siècle de droit comparé en France (1869-1969). Paris: Librairie générale de droit et de jurisprudence, 200.

Roberts, A., Stephan, P. B., Verdier, P. H., \& Versteeg, M. (2015). Comparative International Law: Framing the Field. The American Journal of International Law, 3, 467-474. https://doi.org/10.5305/amerjintelaw.109.3.0467

Ruffert. M. (2007). The Transformation of Administrative Law in Europe (pp. 6). München: Sellier.

Sacco, R. (1991). Legal Formants: A Dynamic Approach to Comparative Law. Install. I-II. American Journal of Comparative Law, 39, 343-401. https://doi.org/10.2307/840784

Scarciglia, R. (2014). Methodological Pluralism and Legal Comparison. In R. Scarciglia, \& W. Menski (Eds.), Islamic Symbols in European Courts (pp. 21-34). Milano: Kluwer.

Scarciglia, R. (2018). Metodi e comparazione giuridica (2nd ed.). Milano: Kluwer-Cedam.

Seerden, R. J. G. H. (2012). Administrative Law of the European Union, its Member and the United States. A Comparative Analysis (3rd ed.). Cambridge: Intersentia Intersentia.

Sordi, B. (2010). Revolution, Rechtsstaat, and the Rule of Law: Historical Reflections on the Emergence of Administrative Law in Europe. In S. Rose-Ackerman, \& P. L. Lindseth (Eds.), Comparative Administrative Law (pp. 23). Cheltenham, UK and Northampton, MA: Edward Elgar.

Twining, W. (2007). Globalization and Comparative Law. In E. Örücü, \& D. Nelken, (Eds.), Comparative Law: A Handbook (pp. 71). Oxford and Portland: Hart.

Wigmore, J. H. (1941). A Kaleidoscope of Justice: Containing Authentic Accounts of Trial Scenes from All Times and Climes. Washington: Washington Law Books.

Zweigert, K., \& Kötz, H. (1998). An Introduction to Comparative Law (pp. 54-74). Oxford and New York: Oxford University Press. 